\title{
ATTRIBUTES OF IRRIGATED RICE AND SOIL SOLUTION AS AFFECTED BY SALINITY LEVELS OF THE WATER LAYER $^{(1)}$
}

\author{
Thiago Isquierdo Fraga ${ }^{(2)}$, Felipe de Campos Carmona $^{(3)}$, Ibanor \\ Anghinoni $^{(4)}$ \& Elio Marcolin(5)
}

\begin{abstract}
SUMMARY
In the State of Rio Grande do Sul, Brazil, flooded rice fields using Patos Lagoon as the source of water for irrigation are subject to be damaged by salinity, since this source is bound to the sea on its southern end. The sensitivity of rice is variable during plant development, being higher in the seedling and reproductive periods. However, there is not enough information about the behavior of plants under salt stress during the course of its development, especially in the vegetative stage. This study evaluated the effect of different levels of salinity of irrigation water on the salinity of soil solution over time and on some plant attributes, during the vegetative stage of rice. The study was conducted in a greenhouse, where seeds of the variety IRGA 424 were sown in pots and irrigated with water with electrical conductivity (ECi) levels of: $0.3,0.75,1.5,3.0$ and $4.5 \mathrm{dS} \mathrm{m}^{-1}$, from the tillering initiation (V4) until the panicle initiation (PI). The evaluations made were the electrical conductiviy of soil solution (ECe), the dry biomass of plants and stems, tillering, height and the transpiration of plants. The ECe increased with the ECi over time, and was determined by water transpiration flux in pots. The ECe values at the end of the experiment were high and, in most cases, higher than the critical values for flooded rice. The growth attributes of rice were negatively affected from ECi of $2.0 \mathrm{dS} \mathrm{m}^{-1}$ and ECe of $4.0 \mathrm{dS} \mathrm{m}^{-1}$.
\end{abstract}

Index terms: electrical conductivity, tillering, vegetative growth, Oryza sativa L.

\footnotetext{
(1) Research done in partnership between the Rice Institute of Rio Grande do Sul (IRGA) and the Department of Soils, Federal University of Rio Grande do Sul (UFRGS). Received for publication in July 2009 and approved in March, 2010.

(2) Agronomist, Federal University of Rio Grande do Sul - UFRGS. Av: Bento Gonçalves, 7712, CEP 91540-000, Porto Alegre (RS). E-mail: isquierdofraga@yahoo.com.br

${ }^{(3)}$ Doctorate student, Graduate Program of Soil Science, UFRGS. E-mail: felipecamposcarmona@hotmail.com. Scholarship of CAPES.

(4) Associate Professor, Graduate Program of Soil Science, UFRGS. E-mail: ibanghi@ufrgs.br

(5) Agronomist, Researcher at IRGA. E-mail: elio-marcolin@irga.rs.gov.br
} 


\title{
RESUMO: ATRIBUTOS DE ARROZ IRRIGADO E DA SOLUÇÃO DO SOLO INFLUENCIADOS POR NÍVEIS DE SALINIDADE DA LÂMINA DE ÁGUA DE IRRIGAÇÃO
}

\begin{abstract}
No Rio Grande do Sul, lavouras de arroz irrigado que utilizam como fonte hidrica a Laguna dos Patos estão sujeitas a sofrer danos pela salinidade, uma vez que esse manancial liga-se ao mar em sua extremidade sul. A sensibilidade do arroz é variável no decorrer do ciclo de desenvolvimento da cultura, sendo maior no período de plântula e no reprodutivo. No entanto, pouco se sabe sobre o comportamento das plantas em condições de estresse salino no decorrer do seu ciclo de desenvolvimento, principalmente no período vegetativo. Este trabalho teve como objetivo avaliar o efeito de diferentes níveis de salinidade da água de irrigação sobre a salinidade da solução do solo e sobre atributos de planta durante o período vegetativo do arroz. O trabalho foi conduzido em casa de vegetação, onde o cultivar IRGA 424 foi semeado em vasos, que foram irrigados com água com níveis de condutividade elétrica (CEi) de: 0,3; 0,75; 1,5; 3,0; e 4,5 dS m $\mathrm{m}^{-1}$ a partir do início do perfilhamento (V4) até a diferenciação do primórdio floral (DPF). Foram avaliados a condutividade elétrica da solução do solo (CEe), a matéria seca da parte aérea e dos colmos, o perfilhamento, a estatura e a transpiração das plantas. A CEe aumentou com a CEi ao longo do tempo e foi determinada pelo fluxo de transpiração de água em ambiente confinado. Os valores de CEe atingidos no final do trabalho foram elevados e, na maioria dos casos, superiores aos valores considerados críticos para o arroz irrigado. Os atributos de crescimento do arroz irrigado foram alterados negativamente a partir da CEi de 2,0 $\mathrm{dS} \mathrm{m}^{-1}$ e da CEe de 4,0 dS $\mathrm{m}^{-1}$.
\end{abstract}

Termos de indexação: condutividade elétrica, perfilhamento, crescimento vegetativo, Oryza sativa $L$.

\section{INTRODUCTION}

The salinity is one of the main factors of land degradation in the world, acting negatively on crop growth. In the case of rice (Oryza sativa L.), especially in the coastal areas and floodplains of the State of Rio Grande do Sul, Brazil, the irrigation water salinity can affect large areas of three producing regions: Southern, Internal Coastal Plain and External Coastal Plain, since the main source used in these regions is the Laguna dos Patos lagoon, which is connected to the Atlantic Ocean on its southern edge. This effect occurs both in the winter months because of the prevalence of south winds, as well as in the summer months, when low rainfall, associated with the increased demand for water from the surrounding crops, reduce the level in the lagoon, allowing the entry of saline water from the sea (Marcolin et al., 2005).

The electrical conductivity (EC) is the attribute most often used for monitoring the salinity of the water, and the values at the catchment points of irrigation water around the lagoon have ranged from less than $0.3 \mathrm{dS} \mathrm{m}^{-1}$ up to $7.0 \mathrm{dS} \mathrm{m} \mathrm{m}^{-1}$, over the years (Fraga et al., 2007). The value of the electrical conductivity of irrigation water (ECi) established as critical for rice cultivation in the states of Rio Grande do Sul and Santa Catarina is $2.0 \mathrm{dS} \mathrm{m}^{-1}$ (SOSBAI, 2007). However, this salinity measure is not always a good attribute to evaluate the risk, since the damage to rice is directly related to the salinity of the soil solution in the root zone (effective electrical conductivity - ECe). The tolerance of rice to ECe is up to $3.0 \mathrm{dS} \mathrm{m}^{-1}$, a value considered as critical (Ayers \& Westcot, 1985). The relationship between ECi and ECe depends on the leaching fraction (LF), i.e., the amount of irrigation water that moves below the root zone, which in turn varies with soil texture. The $\mathrm{ECe}$ of $3.0 \mathrm{dS} \mathrm{m}^{-1}$ corresponds to different $\mathrm{ECi}$, according to equation 1 , depending on the soil permeability (Ayers \& Westcot, 1985). Therefore, Zeng \& Shannon (2000) found that the salinity of the soil solution (ECe) from $1.9 \mathrm{dS} \mathrm{m}^{-1}$ was enough to affect rice (cultivar M-202), suggesting the need for studies for the varieties and climatic conditions in southern Brazil.

$$
\mathrm{ECe}=\mathrm{ECi} \div(2.2 \times \mathrm{LF})
$$

The increase in salinity harms the biomass production of rice linearly (Ehrler, 1960, Zeng et al., 2001, Melo et al. 2006; Carmona et al., 2009). This occurs by tillering reduction (Castillo et al., 2007) and plant height reduction (Gain et al., 2004; Motamed et al., 2008). The primary cause of the damage caused by salinity may be related to photosynthetic rate and growth of leaf tissues (Cramer, 2003). In both cases, the stress can affect cell expansion at the leaf growth zone, which can be direct or indirect (Setter et al., 1983). The direct effect of stress occurs in the photosynthetic apparatus and the indirect is on the growth, which causes a reduction in the delivery of photosynthates and water, by the decrease in plant transpiration (Maas \& Nieman, 1978). 
The tolerance of rice to salinity varies with the plant stage. Seedling and flowering stages are considered critical (Pearson, 1959). However, depending on the cultivar and the crop cycle, exposure to salinity only in the vegetative stage can cause yield losses even greater than those observed when exposure occurs in the so-called critical periods (Zeng et al., 2001). The different sensitivity to salinity between the various stages of growth is one of the factors that difficults the identification of tolerant phenotypes (Zeng et al., 2003). Thus, the performance of the plant in the vegetative stage will affect the accomplishment of the yield components formed later, in the reproductive phase.

The breeding programs for irrigated rice in Rio Grande do Sul have been developed, mostly, in conditions of low or null salinity. Therefore, resistant genotypes are not expected to be found among varieties released in recent years (Marcolin et al., 2005). However, the constant release of new varieties suggests that studies must be conducted periodically in order to identify possible promising materials, with respect to salt tolerance.

This study aimed to evaluate the effects of different levels of irrigation water salinity on the root zone salinity and on some attributes of the variety IRGA 424 during the vegetative stage.

\section{MATERIAL AND METHODS}

The study was conducted in a greenhouse of the Soil Department of Agronomy, Federal University of Rio Grande do Sul (UFRGS), from October 2006 to March 2007. An Albaqualf was used, from the Internal Coastal Plain of Rio Grande do Sul, collected from the topsoil $(0-20 \mathrm{~cm})$. The sandy loam textured soil was air-dried and sieved in a mesh of $5 \mathrm{~mm}$ in diameter and had average values, according to the method proposed by Tedesco et al. (1995), of $230 \mathrm{~g} \mathrm{~kg}^{-1}$ of clay, $20 \mathrm{~g} \mathrm{dm}^{-3}$ of organic matter, a pH in water of $4.9 ; 1.1$, 2.6 and $1.1 \mathrm{cmol}_{\mathrm{c}} \mathrm{dm}^{-3}$ of $\mathrm{Al}, \mathrm{Ca}$ and $\mathrm{Mg}(\mathrm{KCl}$ $1.0 \mathrm{~mol} \mathrm{~L}^{-1}$ ), respectively, $118 \mathrm{mg} \mathrm{dm}^{-3}$ of available $\mathrm{K}$ (Mehlich-1), $318 \mathrm{mg} \mathrm{dm}^{-3}$ of available Na (Mehlich-1), $40 \mathrm{mg} \mathrm{dm}-3$ of available P (Mehlich-1), $4.4 \mathrm{cmol}_{\mathrm{c}} \mathrm{dm}^{-3}$ of exchangeable $\mathrm{Al}+\mathrm{H}(\mathrm{SMP})$ and $8.4 \mathrm{cmol}_{\mathrm{c}} \mathrm{dm}^{-3}$ of $\mathrm{CEC}_{\mathrm{pH}}$ 7.0.

A volume of $11 \mathrm{dm}^{3}$ of soil was placed in pots of $13 \mathrm{~L}$, being adjusted to a density of $1.2 \mathrm{~kg} \mathrm{dm}^{-3}$. Water was added to reach the moisture corresponding to field capacity. Fertilization consisted of the application, prior to planting, of $0.22 \mathrm{~g}$ of $\mathrm{N}, 0.17 \mathrm{~g}$ of S, $1.32 \mathrm{~g}$ of $\mathrm{P}_{2} \mathrm{O}_{5}$ and $\mathrm{K}_{2} \mathrm{O}$ of $0.88 \mathrm{~g} \mathrm{pot}^{-1}$ in the form of ammonium sulphate, triple superphosphate and potassium chloride, respectively. After preparing the pots, 20 seeds of the variety IRGA 424 (short stature, medium cycle, long and fine grains and high yield capacity) were taken into the soil to germinate. When the plants reached the V4 stage (four fully expanded leaves), according to the scale proposed by Counce et al. (2000), a top-dressing was made of $1.1 \mathrm{~g} \mathrm{pot}^{-1}$ of $\mathrm{N}$ and $0.66 \mathrm{~g}$ of $\mathrm{K}_{2} \mathrm{O}$ as urea and potassium chloride, respectively.

The levels of ECi adopted from tillering (V4) to panicle initiation (PI) were: 0.3 (control), $0.75,1.5$, 3.0 and $4.5 \mathrm{dS} \mathrm{m}^{-1}$. These levels were maintained in the water layer by the addition of a saline solution of sodium chloride, except for the control, which received water free from salinity. The water layer was monitored every two days, setting up its ECi and its depth $(5 \mathrm{~cm})$ by the addition of a saline solution in order to obtain the level of salinity of each treatment. The amount of $\mathrm{NaCl}$ added to the treatments was obtained according to equation 2 .

$$
\begin{aligned}
& \mathrm{NaCl}\left(\mathrm{g} \mathrm{L}^{-1}\right)=-0,1044+0,0319(\mathrm{CEi})^{2} \\
& \quad+0,4485(\mathrm{CEi}) ;\left(\mathrm{R}^{2}=0,99 ; \mathrm{p}<0,01\right)
\end{aligned}
$$

The pots were arranged according to a randomized block design with five treatments and three replications. Additional pots of control treatment were used to check the beginning of panicle initiation of the main stem. After this evaluation, these pots were discarded.

Soil solution collectors were installed in the pots to determine the ECe. The devices, developed by Silva et al. (2003), consisted of a PVC pipe that served as the support; a plastic hose introduced into the support tube at one end and connected to the collector tube, which was coated with a nylon net at both ends, and positioned at $5 \mathrm{~cm}$ deep in the soil. Samples were collected with $60 \mathrm{~mL}$ syringes, and the volume collected was approximately $50 \mathrm{~mL}$. The samples of solution were taken at 17, 25,33, 39 and 47 days after the onset of irrigation (DAOI). The last sampling, 47 DAOI coincided with the beginning of the panicle initiation in the control treatment.

Transpiration of rice plants was determined based on the evaporation of three pots, without plants, arranged randomly. The volume of water of these pots was completed until the water layer reached $5 \mathrm{~cm}$ deep, with the same frequency of the other pots with plants. As the volume of water added in the pots with and without plants was known, it was possible to establish the transpiration of plants in each experimental unit, subtracting the volume of water added in the treatments by the average volume added in the reference pots.

At the end of the experiment, when the plants reached the PI, the height and number of tillers was determined. Afterward, the plants were cut close to the ground and dried in an oven with air-forced ventilation at approximately $60^{\circ} \mathrm{C}$, until constant weight, when the dry biomass of plants and stems were determined. The data were submitted to regression analysis, with the assistance of the graphical-statistical program SigmaPlot ${ }^{\circledR}$. The equations that best fit the data were used, presenting the statistical significance of regression, by the $\mathrm{F}$ test, 
with the coefficient of determination. Additionally, the coefficients of the Pearson correlation between the attributes of the plants evaluated were determined.

\section{RESULTS \& DISCUSSION}

\section{Effective electrical conductivity (ECe)}

The effective electrical conductivity of the soil solution (ECe) next to the roots ( $5 \mathrm{~cm}$ deep) in the control $\left(0.30 \mathrm{dS} \mathrm{m}^{-1}\right)$ remained constant over the time of flooding (Figure 1a). Its values (between 1.5 and $1.8 \mathrm{dS} \mathrm{m}^{-1}$ ) were, however, between five and six times greater than the electrical conductivity of the water layer (ECi) (Table 1). A higher ECe in this treatment may be related to the salt effect of fertilizers applied (incorporated and top dressing) in the early stage of rice development, as well as to the electrochemical reactions that occur in waterlogged soil, which increases the concentration of ions in the soil solution (Ponnamperuma, 1972). This occurs because of the displacement of cations adsorbed to soil colloids, especially $\mathrm{Ca}^{2+}, \mathrm{Mg}^{2+}$ and $\mathrm{K}^{+}$, and due to the high concentration of $\mathrm{Fe}^{2+}$ and $\mathrm{Mn}^{2+}$ in the soil solution, resultant of the $\mathrm{Fe}^{3+}$ and $\mathrm{Mn}^{4+}$ oxides reduction (DeDatta, 1981).

The ECe in the first evaluation of the other treatments, in the seventeenth day of flooding (Figure 1a) shows similar values between each other and is comparable to the control (1.6 to $\left.1.8 \mathrm{dS} \mathrm{m}^{-1}\right)$. Based on this assessment, this increase gets differentiated with the level of salinity (Figure 1a), but with an abrupt increase to 47 days after the onset of flooding, in which treatment with ECi of $0.75 \mathrm{dS} \mathrm{m}^{-1}$ reaches the value of $3.0 \mathrm{dS} \mathrm{m} \mathrm{m}^{-1}$ and around $4.5 \mathrm{dS} \mathrm{m}^{-1}$ in the other treatments, reaching and exceeding, respectively, the value which is considered critical $\left(3.0 \mathrm{dS} \mathrm{m}^{-1}\right)$ for rice production (Ayers \& Westcot, 1985). This electrical conductivity reflects the levels of salts in the sample layer $(5 \mathrm{~cm})$, as verified by the content of sodium chloride in the samples (Figure 1b).

Table 1. Ratio between the effective electrical conductivity (ECe) and electrical conductivity of the water layer (ECi), throughout the rice development, according to $\mathrm{ECi}$

\begin{tabular}{lccccc}
\hline & \multicolumn{5}{c}{ Dias após alagamento } \\
\cline { 2 - 6 } & $\mathbf{1 7}$ & $\mathbf{2 5}$ & $\mathbf{3 3}$ & $\mathbf{3 9}$ & $\mathbf{4 7}$ \\
\hline \multirow{2}{*}{$\mathrm{dS} \mathrm{m}^{-1}$} & \multicolumn{5}{c}{ Razão ECe/ECi } \\
\cline { 2 - 6 } 0.3 & 5.53 & 6.00 & 5.89 & 5.00 & 5.67 \\
0.75 & 2.13 & 2.35 & 2.35 & 2.27 & 4.25 \\
1.5 & 1.19 & 1.21 & 1.31 & 1.55 & 2.82 \\
3.0 & 0.60 & 0.68 & 0.78 & 0.87 & 1.50 \\
4.5 & 0.40 & 0.50 & 0.56 & 0.59 & 0.98 \\
\hline
\end{tabular}
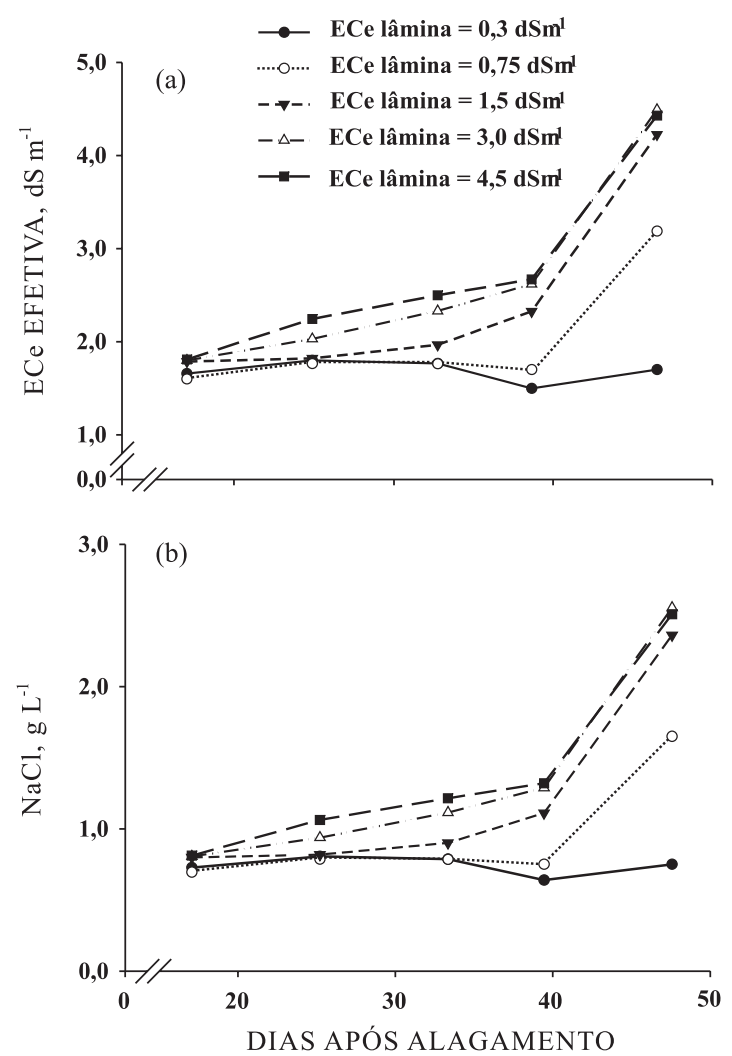

Figure 1. Effective electrical conductivity - ECe (a) and content of sodium chloride (b) of the soil solution throughout rice development according to the electrical conductivity of the water layer (ECi).

In confined systems, as in the present study, all the added salt contained in saline solutions remains in the pot, which creates a cumulative effect in the root zone. Thus, the determinant factor of these increases in ECe should be related to the intensity of water transpiration by plants. Although the cumulative transpiration flux of water has decreased (Figure 2a) with increasing salinity, the salt flow toward the plant roots increased significantly (Figure $2 \mathrm{~b}$ ) with the level of salinity of the water layer over time. ECe values between 7 and $8 \mathrm{dS} \mathrm{m} \mathrm{m}^{-1}$, were also obtained after 42 days of flooding in pots, with the maintenance of the water layer at 3.0 to $6.0 \mathrm{dS} \mathrm{m} \mathrm{m}^{-1}$ (Schoenfeld et al., 2007).

The sharp increase in salinity in the soil solution along the roots may also occur with rice being grown in the field, since the leaching fraction (Equation 1) may be very low, because the hydraulic conductivity is often close to zero, which can occur in lowland soils of southern Brazil, due to the occurrence of accentuated textural gradient in depth (Streck et al., 2008). Thus, Boivin et al. (2002), in a fieldwork performed in Senegal in different years and weather conditions (dry season and wet season), found that the ECe of a Vertisol increased over irrigation time 

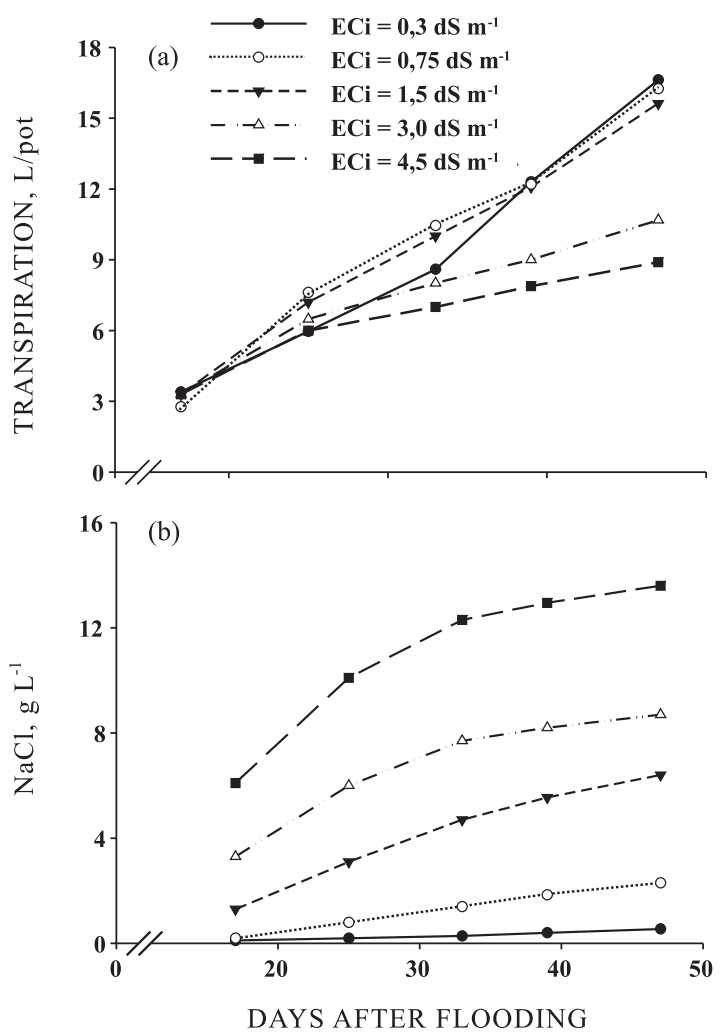

Figura 2. Amount of water transpired (a) and amount of sodium supplied in the transpiration flow (b) throughout rice development, according to the electrical conductivity of the water layer (ECi). from $0.3 \mathrm{dS} \mathrm{m}^{-1}$, at the beginning of irrigation, to $1.2 \mathrm{dS} \mathrm{m}^{-1}$ at the end of the rice cycle. These authors emphasized that a fieldwork should be discussed based on the movement of water and solutes in the soil profile, dissolution and precipitation of salts, cation exchange, geochemical equilibrium and redox reactions, as well as absorption by plants. Most of these phenomena are related to rapid changes in temperature, microbial activity and plant growth itself.

\section{Growth of rice due to the salinity of both water and soil solution}

The irrigation water salinity caused a quadratic reduction of the dry biomass of shoots $(p<0.01)$, dry biomass of stems $(p<0.05)$ and height $(p<0.01)$ of plants; and a linear reduction of the number of tillers $(p<0.01)$ (Figure 3). The steeper declines occurred from the ECi between 2.0 and $3.0 \mathrm{dS} \mathrm{m}^{-1}$, but closer to $2.0 \mathrm{dS} \mathrm{m}^{-1}$ (Figure 3). An exception, however, is made to the number of tillers (Figure 3c), which begins to be affected from the ECi of $1.5 \mathrm{dS} \mathrm{m}^{-1}$. These results are consistent with the critical value of $2.0 \mathrm{dS} \mathrm{m} \mathrm{m}^{-1}$, used for flooded rice in southern Brazil (SOSBAI, 2007). Shannon et al. (1998), however, reported a reduction of the biomass of plants from an ECi of $2.9 \mathrm{dS} \mathrm{m}^{-1}$, in the vegetative stage.

The dry biomass of plants (Figure 3a) was the most affected attribute, since it showed a $60 \%$ reduction at the highest salinity level, compared to the control, while the least affected was the dry biomass of stems
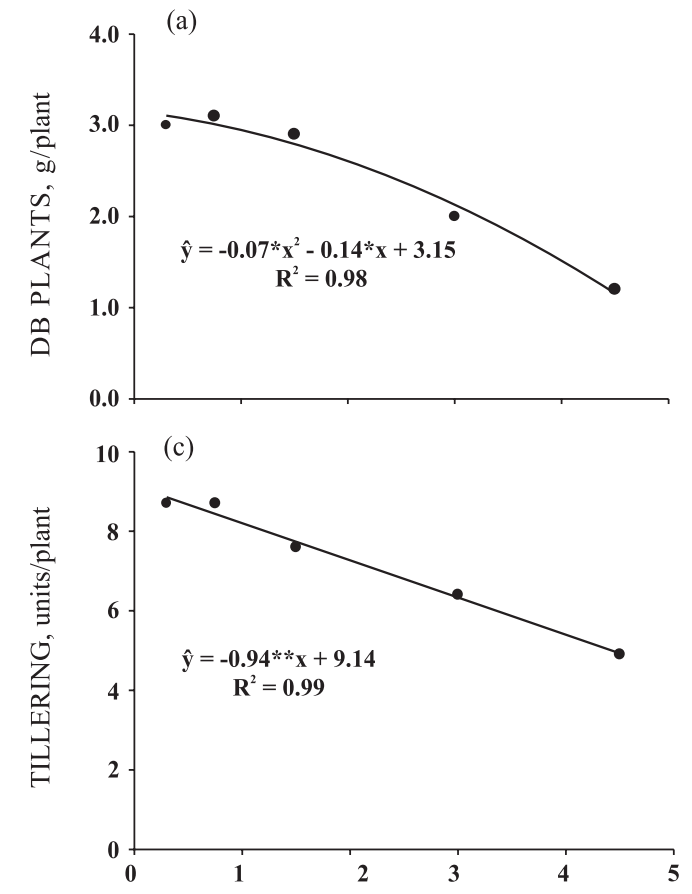
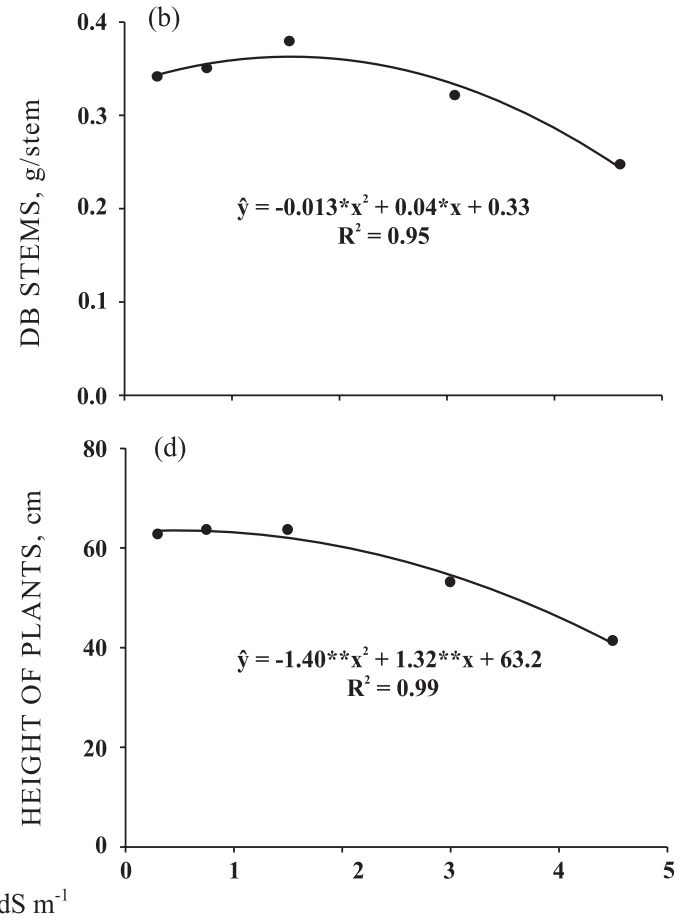

Figure 3. Dry biomass (DB) of plants (a) dry biomass of stems (b), tillering (c) and height (d) of rice plants, according to the electrical conductivity of the water layer (ECi). *, **: significant at 5 and $1 \%$, respectively, by $F$ test. 
(Figure $3 \mathrm{~b}$ ), with a $28 \%$ reduction. Although the number of tillers per plant (Figure 3c) and height of plants (Figure $3 d)$ were also reduced $(p<0.01)$, the relatively lesser reduction observed in the dry biomass of stems (Figure 3b) indicates a compensatory capacity of the plants, minimizing the effects of stress on this attribute.

In the evaluation of the salinity effect measured in the root zone (ECe) on the growth of rice (Figure 4), there is also a reduction $(p>0.05)$ of the attributes examined, which occurs sharply, however, from the ECe of $4.0 \mathrm{dS} \mathrm{m}^{-1}$ for the dry biomass of shoots (Figure 4a), dry biomass of stems (Figure 4b) and height of plants (Figure 4d), and from $3.0 \mathrm{dS} \mathrm{m}^{-1}$ for the number of tillers (Figure 4c). These values of critical ECe, although higher, are in line with the critical values for the ECi (Figure 3). The critical value found for the ECe $\left(4.0 \mathrm{dS} \mathrm{m}^{-1}\right)$ is, however, higher than the critical value of $3.0 \mathrm{dS} \mathrm{m}^{-1}$, proposed by Ayers $\&$ Westcot (1985). Based on Equation 1, the values of $\mathrm{LF}$ (fraction of water that is leached) would be of 0.45 and 0.60 , respectively for an ECe of 3.0 and $4.0 \mathrm{dS} \mathrm{m}^{-1}$, corresponding to loamy textured and sandy textured soils. In the case of clay soils, the critical ECe is lower, between 1.5 to $2.0 \mathrm{dS} \mathrm{m}^{-1}$, which corresponds to a value of $\mathrm{LF}$ between 0.2 and 0.3 , as found in the valley of Sacramento River, USA, whose critical ECe for flooded rice is $1.9 \mathrm{dS} \mathrm{m}^{-1}$ (Grattan et al., 2002).
In the present study, however, the focus of discussion of the ECe must be directed to the contribution of the transpiration stream of water and salts (Figure 2), which are responsible for the salinity measured along the roots of rice (Figure 1). It is also important to point out that relations between the attributes of rice growth and the attributes of salinity were established with evaluations conducted at the end of the study, when the greatest increase in salinity near of roots was checked.

The effects of salinity on the attributes of rice plants, observed in this study (Figures 3 and 4) are consistent with the results of Alam et al. (2004), Motamed et al. (2008), Welfare et al. (1996) and Castillo et al. (2007). The reduction of plant transpiration with the increase of salinity (Figure 2a) can be imputed to a reduced capacity to absorb water, by the decrease of the osmotic component of soil water potential (Tester $\&$ Davenport, 2003). This hydraulic signal reduces the effective turgor of the growth areas, beyond diminishing the stomatal conductance of leaves, stopping the flow of water, regardless of the atmospheric demand (Cramer, 2003).

In the case of the dry biomass of stems, a low salinity seems to tend to be beneficial (Figure $3 b$ ), as also reported by Cui et al. (1995), which observed an increase in the number and weight of grains per panicle. Similarly, Zeng \& Shannon (2000) observed
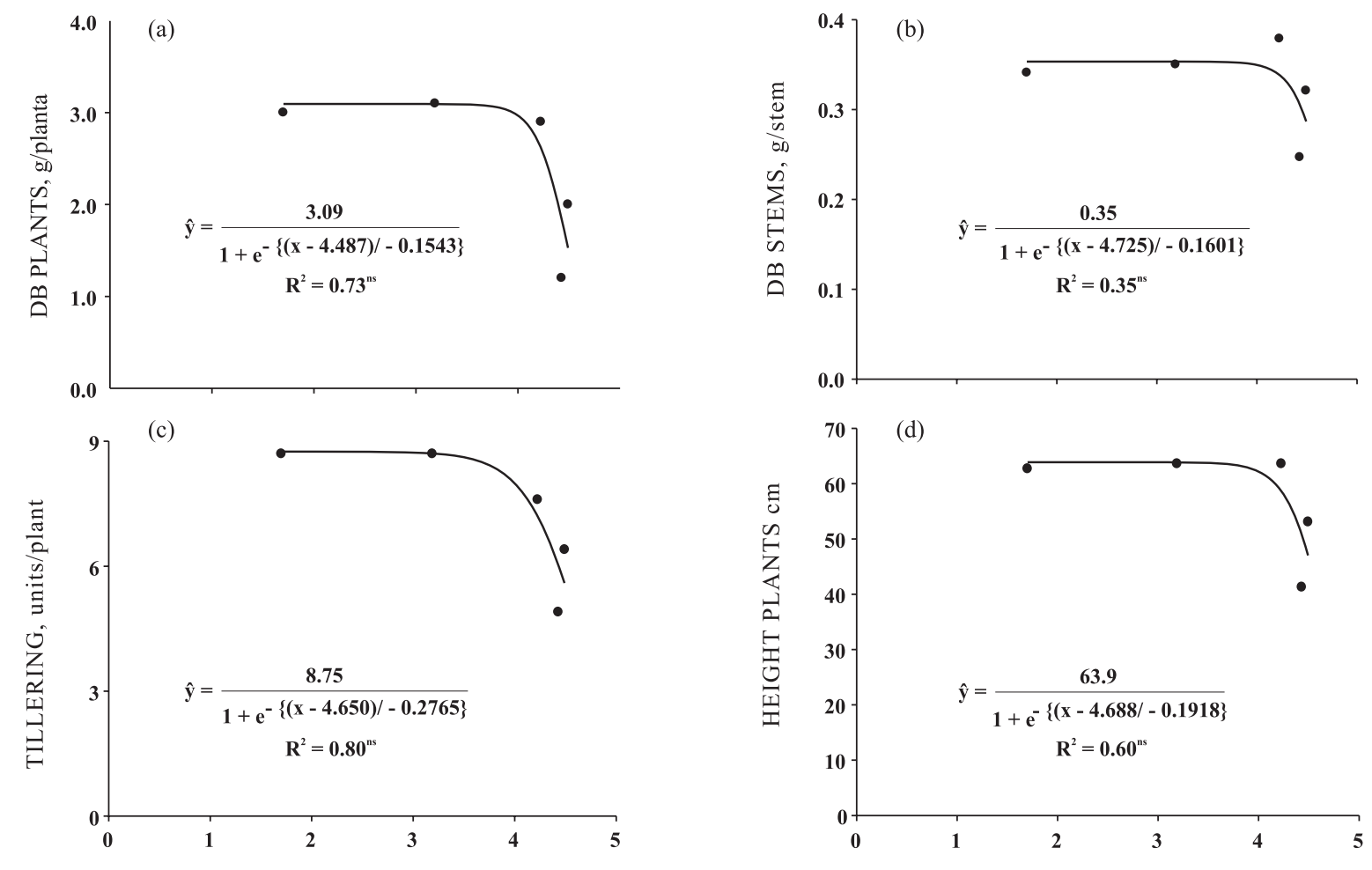

Figure 4. Dry biomass (DB) of plants (a) dry biomass of stems (b), tillering (c) and height (d) of rice plants, according to the electrical conductivity of the soil solution (ECe) at the end of the study. 
an increase in the number of grains per panicle and grain yield when rice plants were subjected to salinity of irrigation water of $1.5 \mathrm{dS} \mathrm{m}^{-1}$ only in the vegetative stage (V4 DPF).

In general, the best correlation between the plant attributes (Table 2) occurred with the dry biomass of plants, especially with the number of tillers $(r=0.98$, $p<0.01)$ and height of plants $(r=0.99, p<0.01)$. The negative effects of salinity on the dry biomass of plants are related to a transpiration decrease (Figure 2a), by its high correlation with leaf area index (Asch et al., 2005), which causes a reduction in the assimilation of photosynthetically active radiation for the production of biomass (Monteith, 1994). In addition, the stomatal closure generates a series of deleterious effects, culminating in a reduced accumulation of photo assimilates by the leaves and therefore lower production of biomass (Sultana et al., 1999). Reduction of plant growth with the increase of salinity can also be attributed to changes in the partitioning of photoassimilates (Zeng et al., 2003) due to an increase of processes of energy consumption, such as osmotic adjustment and active transport of ions, by the excess salts in the plant (Asch et al., 2000). Plant height reflects the length of the longest leaf, which is the youngest (Welfare et al., 1996). A lower production of plant dry matter (Figures 3a and 4a), therefore, results in a lower emission of new leaves by decreasing emissions of tillers (Figures 3c and 4c), which will such as calcium and magnesium (Barber, 1995), affecting plant growth; and toxic ions, like sodium, as rice suffers from excessive absorption of this ion by photosynthetically active tissues, which leads to losses in yield. According to Asch et al. (2005), the governance of absorption and distribution of sodium in tissues is an important characteristic for resistance to salinity, preferably combined with a high tolerance to the presence of $\mathrm{Na}$ in the leaves. The immobilization of this element in some tissues, like the sheath of the leaves may be related to the rate of transpiration, as this determines the speed of transport of ions in the xylem, and a slower transport would enable the plant to store sodium in tissues physiologically less active. Thus, rice varieties tolerant to salinity would have an independent mechanism of transpiration, which would immobilize the sodium in these tissues, protecting the other leaf structures from excessive sodium accumulation. This seems to have not been the case of IRGA 424, used in this study, since all the attributes of the plant were negatively affected by salinity from $3.0 \mathrm{dS} \mathrm{m}^{-1}$ (Figure 3).

The dry biomass of stems was the only attribute that did not correlate $(p>0.05)$ with the tillering and transpiration (Table 2). In that case, it must be highlighted again the compensatory capacity of the plants which had, somewhat, the ability to minimize losses of dry biomass of stems (Figure 3b), with the reduction of tillering (Figure 3c) up to an ECi of $3.0 \mathrm{dS} \mathrm{m}^{-1}$.

Table 2. Pearson correlation coefficient between the dry biomass (DB) of plants, dry biomass of stems, number of tillers, height and transpiration of irrigated rice plants

\begin{tabular}{|c|c|c|c|c|c|}
\hline Attribute & DB plants & DB stems & Tillering & Height & Transpiration \\
\hline DB plants & & $0.91^{*}$ & $0.98^{* *}$ & $0.99 * *$ & $0.98^{* *}$ \\
\hline DB stems & & - & 0.82 & $0.96^{*}$ & 0.85 \\
\hline Tillering & & & - & $0.95^{*}$ & $0.97 * *$ \\
\hline Height & & & & - & $0.96^{*}$ \\
\hline Transpiration & & & & & - \\
\hline
\end{tabular}

$* * * *$ significant at 5 and $1 \%$, respectively.

result, consequently, in a reduction of the rice height (Figures 3d and 4d). For Cramer (1993), in addition to genotypic differences in salt tolerance, the mechanisms that inhibit leaf elongation, when exposed to short periods of stress, are apparently specific to each species of grass.

Transpiration of rice correlated $(\mathrm{r}=0.98, \mathrm{p}<0.01)$ with the dry biomass of plants, tillering $(r=0.97$, $p<0.01)$ and height $(r=0.96, p<0.05)$. The effect of excessive amounts of salts on the transpiration of plants should be considered as one of the main factors that determine the tolerance of rice to salinity, since the efficiency in water use will determine the supply by mass flow and hence absorption of macronutrients

\section{CONCLUSIONS}

1. The electrical conductivity of soil solution (ECe) increases with the electrical conductivity of the water layer (ECi) over time and is determined by the transpiration flow of water in confined medium.

2. Values of ECe recorded at the end of the study are high and, in most cases, higher than those values that are considered critical to the rice.

3. The growth attributes of rice, especially the dry biomass of plants are negatively affected by both salinity of the irrigation water layer and the soil solution. 
4. The growth of rice begins to be affected by the ECi from $2.0 \mathrm{dS} \mathrm{m}{ }^{-1}$, which is in agreement with the value adopted as critical in southern Brazil, and by the ECe from $4.0 \mathrm{dS} \mathrm{m}^{-1}$.

\section{LITERATURE CITED}

ASCH, F.; DINGKUHN, M. \& DÖRFFLING, K. Salinity increases $\mathrm{CO}_{2}$ assimilation but reduces growth in fieldgrowth, irrigated rice. Plant Soil, 218:1-10, 2000.

ASCH, F.; WIMMER, M.A.; DAHAL, K.P. \& DAS, U.S. Boron distribution shows sodium distribution in rice leaves to be independent of transpiration. In: CONFERENCE ON INTERNATIONAL AGRICULTURAL RESEARCH FOR DEVELOPMENT, 2005, Stuttgart. Proceeding. Stuttgart, Deutscher Tropentag, 2005.

AYERS, R.S. \& WESTCOT, D.W. Water quality for agriculture. Roma, Food and Agriculture Organization of the United Nations, 1985. 174p.

ALAM, M.Z.; STUCHBURY, T.; NAYLOR, R.E.L. \& RASHID, M.A. Effect of salinity on growth of some modern rice cultivars. J. Agron., 3:1-10, 2004.

BARBER, S.A. Soil nutrient bioavailability: A mechanistic approach. 2.ed. New York, John Wiley \& Sons, 1995. $414 \mathrm{p}$.

BOIVIN, P.; FAVRE, F.; HAMMECKE, C.; MAEGHT, J.L.; DELARIVIE'RE, J.; POUSSIN, J.C. \& WOPEREIS, M.C.S. Processes driving soil solution chemistry in a flooded ricecropped vertisol: Analysis of long-time monitoring data. Geoderma, 110:87-107, 2002.

CARMONA, F.C.; ANGHINONI, I.; MEURER, E.J.; HOLZSCHUH, M. \& FRAGA, T.I. Estabelecimento do arroz irrigado e absorção de cátions em função do manejo da adubação potássica e nível de salinidade do solo. $\mathrm{R}$. Bras. Ci. Solo, 33:371-382, 2009.

CASTILLO, E.G.; TUONG, T.P.; ISMAIL, A.M. \& INUBUSHI, K. Response to salinity in rice: Comparative effects of osmotic and ionic stresses. Plant Prod. Sci., 10:159-170, 2007.

COUNCE, P.A.; KEISLING, T.C. \& MITCHELL, A. A uniform, objective, and adaptive system for expressing rice development. Crop Sci., 40:436-443, 2000.

CRAMER, G.R. Differential effects of salinity on leaf elongation kinetics of three grass species. Plant Soil, 253:233-244, 2003.

CUI, H.; TAKEOKA, Y. \& WADA, T. Effect of sodium chloride on the panicle and spikelet morphogenesis in rice. Japanese J. Crop Sci., 64:593-600, 1995.

DeDATTA, S.K. Principles and practices of rice production. New York, John Wiley, 1981. 618p.

EHRLER, W. Some effects of salinity on rice. Bot. Gazette, 122:102-104, 1960
FRAGA, T.I.; MARCOLIN, E.; MACEDO, V.R.M.; GENRO JR, S.A.; SCHOENFELD, R. \& ANGHINONI, I. Salinidade da água da Laguna dos Patos utilizada no arroz irrigado. In: CONGRESSO BRASILEIRO DE ARROZ IRRIGADO, 5.; REUNIÃO DA CULTURA DO ARROZ IRRIGADO, 27., Pelotas, 2007. Anais. Pelotas, Sociedade Sul-Brasileira de Arroz Irrigado, 2007. v.2. p.405-407.

GAIN, P.; MANNAN, M.A.; PAL, P.S.; MAHEB HOSSAIN, M. \& PARVIN, S. Effect of salinity on some yield attributes of rice. Pak. J. Biol. Sci., 7:760-762, 2004.

GRATTAN, S.R.; ZENG, L.; SHANNON, M.C. \& ROBERTS, S.R. Rice is more sensitive to salinity than previously thought. California Agric., 56:189-195, 2002.

MAAS, E.V. \& NIEMAN, R.H. Physiology of plant tolerance to salinity. In: JUNG, G.A. Crop tolerance to suboptimal land conditions. Am. Soc. Agron. Pub., 32:277-299, 1978.

MARCOLIN, E.; ANGHINONI, I.; MACEDO, V.M.; GENRO JUNIOR, S.A. \& VEZZANI, F.M. Salinidade da água na cultura do arroz no Rio Grande do Sul. Lav. Arroz., 53:27$38,2005$.

MELO, P.C.S.; ANUNCIAÇÃO FILHO, C.J.; OLIVEIRA, F.J.; BASTOS, G.Q.; TABOSA, J.N.; SANTOS, V.F. \& MELO, M.R.C.S. Seleção de genótipos de arroz tolerantes a salinidade na fase de germinação. Ci. Rural, 36:58-64, 2006.

MONTEITH, J.L. Validity of the correlation between intercepted radiation and biomass. J. Agric. Meteor., 68:213-220, 1994

MOTAMED, M.K.; ASADI, R.; REZAEI, M. \& AMIRI, E. Response of high yielding rice varieties to $\mathrm{NaCl}$ salinity in greenhouse circumstances. Afr. J. Biotechnol., 7:38663873,2008 .

PEARSON, G.A. Factors influencing salinity of submerged soils and growth of Caloro rice. Soil Sci., 87:198-206, 1959

PONNAMPERUMA, F.N. The chemistry of submerged soils. Adv. Agron., 24:29-96, 1972.

SCHOENFELD, R.; MARCOLIN, E.; GENRO JR, S.A.; MACEDO, V.R.M. \& ANGHINONI, I. Crescimento do arroz em função da salinidade da água de irrigação e da solução dos solos em torno da Laguna dos Patos. In: CONGRESSO BRASILEIRO DE ARROZ IRRIGADO, 5.; REUNIÃO DA CULTURA DO ARROZ IRRIGADO, 27., Pelotas, 2007. Anais. Pelotas, Sociedade Sul-Brasileira de Arroz Irrigado, 2007. v.2. p.414-415.

SOCIEDADE SUL-BRASILEIRA DE ARROZ IRRIGADO SOSBAI. Recomendações técnicas da pesquisa para o Sul do Brasil. Pelotas, 2007. 161p.

SETTER, T.L.; GREENWAY, H. \& KUO, J. Inhibition of cell division by high external $\mathrm{NaCl}$ concentration in synchronized cultures of Chlorella emersonis. Austr. J. Plant Physiol., 9:179-196, 1983.

SHANNON, M.C.; RHOADES, J.D.; DRAPER, J.H.; SCARDACI, S.C. \& SPYRES, M.D. Assessment of salt tolerance in rice cultivars in response to salinity problems in California. Crop Sci., 38:394-398, 1998. 
SILVA, L.S.; SOUSA, R.O. \& BOHNEN, H. Alterações nos teores de nutrientes em dois solos alagados, com e sem plantas de arroz. Ci. Rural, 33:487-490, 2003.

STRECK, E.D.; KAMPF, N.; DALMOLIN, R.S.D.; KLAMT, E.; NASCIMENTO, P.C.; SCHNEIDER, P.; GIASSON, E. \& PINTO, L.F.S. Solos do Rio Grande do Sul. 2.ed. Porto Alegre, EMATER/RS-ASCAR, 2008. 222p.

SULTANA, N.; IKEDA, T. \& ITOH, R. Effect of $\mathrm{NaCl}$ salinity on photosynthesis and dry matter accumulation in developing rice grains. Environ. Exper. Bot., 42:211-220, 1999.

TEDESCO, J.M.; GIANELLO, C.; BISSANI, C.A.; BOHNEM, H. \& VOLKWEISS, S.J. Análise de solo, plantas e outros materiais. 2.ed. Porto Alegre, Universidade Federal do Rio Grande do Sul, 1995. 174p. (Boletim Técnico de Solos, 5)
TESTER, M. \& DAVENPORT, R. $\mathrm{Na}^{+}$tolerance and $\mathrm{Na}^{+}$ transport in higher plants. Ann. Bot., 91:503-527, 2003.

ZENG, L.; POSS, J.A.; WILSON, C.; DRAZ, A.S.E.; GREGORIO, G.B. \& GRIEVE, C.M. Evaluation of salt tolerance in rice genotypes by physiological characters. Euphytica, 129:281-292, 2003.

ZENG, L. \& SHANNON, M.C. Salinity effects on seedling growth and yield components of rice. Crop Sci., 40:9961003, 2000.

ZENG, L.; SHANNON, M.C. \& LESCH, S.M. Timing of salinity stress affects rice growth and yield components. Agric. Water Manag., 48:191-206, 2001.

WELFARE, K.; FLOWERS, T.J.; TAYLOR, G. \& YEO, R. Additive and antagonistic effects of ozone and salinity on the growth, ion contents and gas exchange of five varieties of rice (Oryza sativa L.) Environ. Poll., 92:257-256, 1996. 